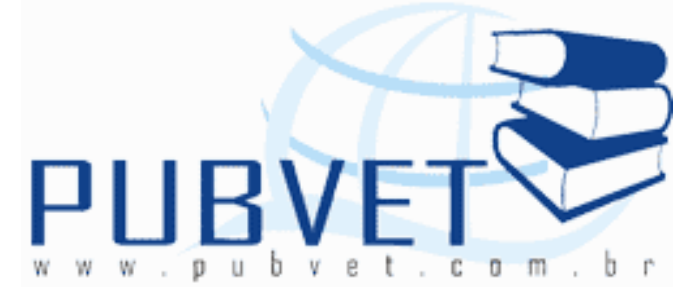

PUBVET, Publicações em Medicina Veterinária e Zootecnia.

\title{
Prevalence of helminth eggs in dog feces in urban areas of Pelotas, RS, Brazil
}

Bianca Delgado Menezes Hofstätter ${ }^{1}$, Anelise Oliveira da Silva Fonseca ${ }^{2}$, Fernando de Souza Maia Filho ${ }^{3}$, Júlia de Souza Silveira Valente ${ }^{4}$, Sônia de Avila Botton $^{5}$, Daniela Isabel Brayer Pereira ${ }^{6 *}$

1 Médica Veterinária, mestranda do Programa de Pós Graduação em Parasitologia, Departamento de Microbiologia e Parasitologia, Instituto de Biologia, Universidade Federal de Pelotas (UFPel), RS, Brazil.

2 Médica Veterinária, Doutoranda do Programa de Pós Graduação em Veterinária, Faculdade de Veterinária, UFPel, RS, Brasil.

${ }^{3}$ Farmacêutico, Doutorando do Programa de Pós Graduação em Parasitologia, Departamento de Microbiologia e Parasitologia, Instituto de Biologia, UFPel, RS, Brasil.

${ }^{4}$ Acadêmica do Curso de Biologia, Bolsista PROBIC (FAPERGS), Departamento de Microbiologia e Parasitologia, Instituto de Biologia, UFPel, RS, Brasil.

${ }^{5}$ Médica Veterinária, Professor Adjunto, Doutor, Departamento de Medicina Veterinária Preventiva, Centro de Ciências Rurais, Universidade Federal de Santa Maria (UFSM), RS, Brazil. Campus Universitário, Santa Maria, RS, Brasil. ${ }^{6 *}$ (Corresponding author) Médica Veterinária, Professor Adjunto, Doutor, Departamento de Microbiologia e Parasitologia, Instituto de Biologia. Universidade Federal de Pelotas, Pelotas, RS. Campus Universitário Capão do 
Leão, s/no, Prédio 18, sala 14. CEP: 96010-900, Capão do Leão, Brasil. Fone: (53)32757338. Fax: (53)32757335. E-mail: danielabrayer@gmail.com.

\section{Abstract}

The aim of this study was to determine the prevalence of helminthes eggs in dog feces collected in public areas in Pelotas, RS, Brazil. From January to March of 2012, 15 samples were randomly collected from each of 14 locations in this county. A total of 210 samples were submitted to fecal examinations. The overall prevalence was $57.6 \%$, including both single $(67.8 \%)$ and multiinfections (32.2\%). Ancylostoma spp. had the highest frequency $(88.4 \%)$, followed by Trichuris vulpis (38.8\%). The infection of dogs with intestinal parasites emphasizes the potential risk of zoonotic diseases and the need for educational, control and prevention programs for at-risk populations.

Keywords: dogs, Ancylostoma spp., zoonoses, nematodes.

\section{Prevalência de ovos de helmintos em fezes de cães em áreas urbanas de Pelotas, RS, Brasil}

\section{Resumo}

O objetivo deste estudo foi verificar a prevalência de ovos de helmintos em fezes de cães coletadas em vias públicas de Pelotas, RS. No período de janeiro a março de 2012 foram coletadas aleatoriamente 15 amostras de fezes em 14 pontos da cidade, totalizando 210 amostras, submetidas a exames coproparasitológicos. A prevalência geral foi $57,6 \%$ tanto em mono $(67,8 \%)$ como em multi-infecções (32,2\%). Ancylostoma spp. apareceu em maior frequência $(88,4 \%)$, seguido de Trichuris vulpis $(38,8 \%)$. As infecções enteroparasitárias em cães enfatizam o risco de zoonoses e a necessidade de ações educativas para conscientização da população e adoção de medidas de controle e prevenção.

Palavras-chave: cães, Ancylostoma spp., zoonoses, nematódeo. 


\section{Introduction}

Dogs play an important role as pets in people's lives because dogs provide psychological and social benefits. Conversely, they may also pose a risk to humans because of their ability to transmit infectious agents such as parasites, bacteria, fungi and viruses. The role of the dogs as the definitive hosts of various parasites with zoonotic potential has been widely studied and recognized as an important public health problem (ARAUJO, 2006; CAPUANO \& ROCHA, 2006). Among parasitoses, parasitic infections caused by Toxocara canis (visceral larva migrans), Ancylostoma caninum and Ancylostoma braziliense (cutaneous larva migrans), Echinococcus granulosus (hydatid cyst), Dipylidium caninum and Trichuris vulpis stand out (ARAUJO, 2006; LABRUNA et al., 2006; GUIMARÃES et al., 2007).

The dog population is a determining factor in the level of environmental contamination by eggs and larvae of pathogenic parasites in urban areas (CAPUANO \& ROCHA, 2006). Stray dogs, because they are not included in worm control programs and have free access to public areas, play an important epidemiological role in the contamination of the environment. In addition, this contamination is increased by domiciled dogs that are taken for walks and whose owners do not collect the feces (CAPUANO \& ROCHA, 2006; LABRUNA et al., 2006). Studies evaluating environmental contamination by the intestinal parasites of dogs in different Brazilian cities have shown that these animals are contaminated by various species of parasites with zoonotic potential, among which Ancylostoma spp. has been the most frequent genus, with a prevalence of approximately $73.7 \%$ (CORTÊS et al., 1988; SCAINI et al., 2003; GUIMARÃES et al., 2005; ARAUJO, 2006; CAPUANO \& ROCHA, 2006; LABRUNA et al., 2006; KATAGIRI \& OLIVEIRA-SIQUEIRA, 2008; COELHO et al., 2011). Considering the size of the dog population in Pelotas county, the lack of feces collection in public areas and the scarcity of studies that have assessed the degree of contamination in this city, the present study aimed to determine the parasite prevalence in dog feces found on public roads. 


\section{Materials and methods}

This study was performed in Pelotas, Rio Grande do Sul State, Brazil (31046'19" S, and 52020'33" W), a city with an area of $1610,091 \mathrm{~km}^{2}$ and a population of approximately 328,275 (www.ibge.gov.br). This city is seven meters above sea level and has a humid subtropical climate, with an annual average temperature of $17.5^{\circ} \mathrm{C}, 1379 \mathrm{~mm}$ rainfall/year and a relative humidity of $80 \%$. The estimated dog population is 66,842 . Of these, $46,789(70 \%)$ are semi-domiciled dogs, 6,684 (20\%) are stray dogs, and 13,368 (10\%) are domiciled dogs. In this area, there is one dog for approximately every five people according to the Municipal Department of Health, 2011.

Fifteen fecal samples that had not yet dried were randomly collected from each of 14 different locations on public roads in Pelotas country between January and March 2012. The collection sites included the downtown area $(n=1)$, the outskirts of town $(n=11)$, the Laranjal (Duck Lagoon) beach resort $(n=1)$, and the county kennel $(n=1)$. A total of 210 samples were collected and later submitted to fecal examination (Willis flotation method) with some modifications (SCAINI et al., 2003). Egg identification was based on morphometric characteristics (ANDERSON et. al., 2009).

\section{Results}

The overall prevalence was $57.6 \%$ (121/210) including both single $(67.8 \% ; 82 / 121)$ and multiple $(32.2 \% ; 39 / 121)$ infections. In 36 samples $(29.7 \%)$, the presence of eggs of two different parasite genera was evident, and the combination of Ancylostoma spp. and Trichuris vulpis was the most frequently observed $(25.6 \%)$. The presence of three parasites was observed in only $2.5 \%$ of fecal samples. Ancylostoma spp. had the highest frequency (88.4\%; 107/121), followed by Trichuris vulpis $(38.8 \% ; 47 / 121)$ and Toxocara spp. (7.4\%; 9/121) (Figure 1). Among the areas selected for the study, downtown area and the Laranjal beach, had positivity rates between 33.3\% and $40 \%$. For the remaining collection points, this frequency ranged from 
$53.3 \%$ to $80 \%$. Coincidentally, these areas represent the outskirts of town. In the kennel, $100 \%$ of feces tested contained helminth eggs.

\section{Discussion}

The sampling sites used in this study were chosen at random, prioritizing the collection of feces on public roads. Thus, there was attempt to search for samples from positive or negative animals or from animals of a certain age, breed, sex or origin. The overall prevalence was $57.6 \%$, which is similar to the results of previous studies performed in the last 20 years in Brazil. Furthermore, the $88.4 \%$ Ancylostoma spp. prevalence rate is one of the highest ever reported in this country (CORTÊS et al., 1988; SCAINI et al., 2003; GUIMARÃES et al., 2005; ARAUJO, 2006; CAPUANO \& ROCHA, 2006; LABRUNA et al., 2006; KATAGIRI \& OLIVEIRA-SIQUEIRA, 2008; COELHO et al., 2011). This helminth is a public health concern because it can cause cutaneous larva migrans in humans. This important zoonotic disease results from the penetration of larvae present in soil contaminated by dog feces into the epidermis of susceptible hosts (DAMANTE et al., 2011; CRIADO et al., 2012).

Unlike in other studies (CORTÊS et al., 1988; GUIMARÃES et al., 2005; ARAUJO, 2006; CAPUANO \& ROCHA, 2006; LABRUNA et al., 2006; KATAGIRI \& OLIVEIRA-SIQUEIRA, 2008) in this study, Trichuris vulpis was detected in $38.8 \%$ of fecal samples analyzed. A similar result was reported in Cassino Beach, RS (SCAINI et al., 2003) located $54 \mathrm{~km}$ from Pelotas county. This similarity can be attributed to the type of methodology used and the geographic regions where these two studies were conducted. Factors such as the sampling protocol, the diagnostic technique, the age of the animals and the geographical distribution may explain the results of the research (GUIMARÃES et al., 2005). It is possible that the higher frequencies of Trichuris vulpis are related to the living conditions of stray dogs, which are not treated with anthelmintics. Thus, these animals become important sources of infection for domiciled dogs because $T$. vulpis eggs remain infectious for several months in the environment (LABRUNA et al., 2006). In addition, this parasite also has an 
important effect on public health because it was identified as an agent of enteric infection and visceral larva migrans in humans (SAKANO et al., 1980; DUNN et al., 2002).

It is likely that the finding of low levels of Toxocara spp. (7.4\%), a result that differs from those of other studies (CORTÊS et al., 1988; GUIMARÃES et al., 2005; ARAUJO, 2006; CAPUANO \& ROCHA, 2006; LABRUNA et al., 2006; KATAGIRI \& OLIVEIRA-SIQUEIRA, 2008) occurred because most of the feces were from adult dogs. Although this work did not into consideration the age of the animals, a predominance of adult dogs among dogs with free access to the areas studied was observed.

A higher prevalence of helminth eggs was found in the dog feces from the outskirts of town. Housing complexes for the low-income population are located in these areas. Similar data have been reported previously (CAPUANO \& ROCHA, 2006). It should be noted that lower frequencies were found in the downtown area and at the Laranjal beach (33.3\% and $40 \%$, respectively), where the socio-economic status of the population is higher. However, a large number of stray dogs roaming freely in public areas were observed and a large amount of feces from these animals was observed at all collection points.

These observations are corroborated by the number of both stray and semi-domiciled dogs, which account for $90 \%$ of all dogs in the municipality of Pelotas. In addition, it was noted that most dog owners are do not collect their pets' feces, suggesting that the majority of the population either ignores or neglects the risks of disease transmission. Katagiri \& Oliveira-Sequeira (2008) claimed that the primary reason for the apparent negligence in deworming dogs is the lack of knowledge about the zoonotic potential of intestinal parasites of dogs.

\section{Conclusion}

The high frequency of parasitic infections, especially by Ancylostoma spp. $(88,4 \%)$, in dogs found in this study emphasizes the risk of spread of zoonoses and indicates that there is an urgent need for educational activities to raise the 
HOFSTÄTTER, B.D.M. et al. Prevalence of helminth eggs in dog feces in urban areas of Pelotas, RS, Brazil. PUBVET, Londrina, V. 7, N. 18, Ed. 241, Art. 1595, Setembro, 2013.

awareness of those people responsible for dogs and to promote the adoption of measures to prevent these diseases.

\section{References}

Anderson RC, Chabaut AG, Willmott S. Keys to the nematode parasites of vertebrates. Ed. Cabi Press 2009.

Araujo JV. Helmintoses intestinais em cães da microrregião de Viçosa, Minas Gerais. Rev Ceres 2006; 53(307): 363-365.

Capuano DM , Rocha GM. Ocorrência de parasitas com potencial zoonótico em fezes de cães coletadas em áreas públicas do município de Ribeirão Preto, SP, Brasil. Rev Bras de Epidemiol 2006; 9(1): 81-86.

Coelho WMD, Amarante AFT, Apolinário JC, Coelho NMD, Bresciani KDS. Occurrence of Ancylostoma in dogs, cats and public places from Andradina city, São Paulo state, Brazil. Rev Inst Med Trop São Paulo. 2011; 53(4): 181-184.

Côrtes VA, Pain GV, Filho RAA. Infestação por ancilostomídeos e toxocarídeos em cães e gatos apreendidos em vias públicas, São Paulo (Brasil). Rev Saúde Públ 1988;22(4): 341-343.

Criado PR, Junior WB, Vasconcellos C, Silva CS. Cutaneous larva migrans: A bad souvenir from the vacation. Dermatol Online J 2012; 18(6): 11.

Damante JH, Chinellato LEM, Oliveira FT, Soares CT, Fleury RN. Larva migrans in the oral mucosa: Report of two cases. Braz Dent J 2011; 22(2): 166-170.

Dunn JJ, Columbus ST, Aldeen WE, Davis M, Carroll KC. Trichuris vulpis recovered from a patient with chronic diarrhea and five dogs. J Clin Microbiol 2002; 40(7): 2703-2704.

Guimarães AM, Alves EGL, Rezende GF, Rodrigues MC. Ovos de Toxocara sp. e larvas de Ancylostoma sp. em praça pública de Lavras, MG. Rev Saúde Públ. 2005; 39(2): 293-295.

Katagiri S, Oliveira-Siqueira TCG. Prevalence of dog intestinal parasites and risk perception of zoonotic infection by dog owners in São Paulo State, Brazil. Zoonoses Public Health 2008; 55 : 406-413.

Labruna MB, Pena HFJ, Souza SLP, Pinter A, Silva JCR, Ragozo AMA, Camargo LM, Gennari SM. Prevalência de endoparasitas em cães da área urbana do município de Monte Negro, Rondônia. Arq Inst Bio 2006; 73(2): 183-93.

Scaini CJ, Toledo R, Lovatel R, Dionello MA, Gatti FA, Susin L, Signorini VRM. Contaminação ambiental por ovos e larvas de helmintos em fezes de cães na área central de Balneário Cassino, Rio Grande do Sul. Rev Soc Bras Med Trop 2003; 36(5): 617-619.

Sakano T, Hamamoto K, Kobayashi Y, Sakata Y, Tsuji M, Usui T. Visceral larva migrans caused by Trichuris vulpis. Arch Dis in Child. 1980; 55: 631-633. 


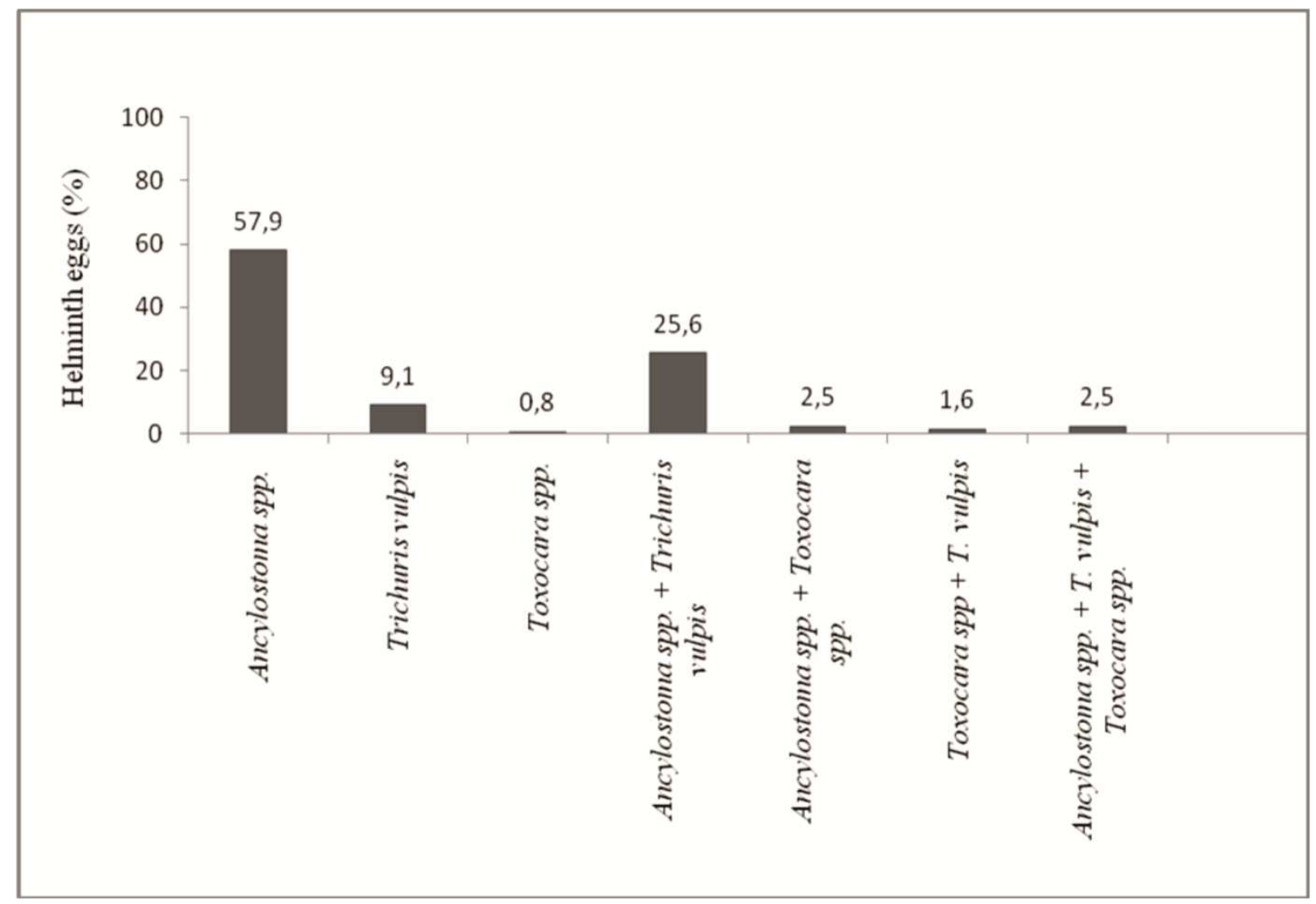

Figure 1: Prevalence of helminth eggs in dog feces on public roads in Pelotas, Brazil, in the period January-March 2012. 